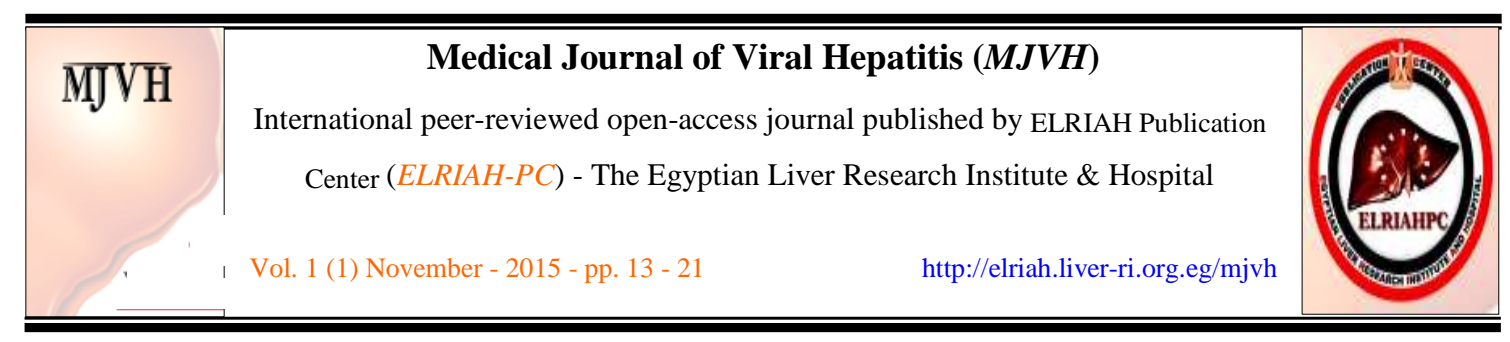

Original article

\title{
Seroprevalence of hepatitis A virus infection in patients with chronic liver diseases: Do we need to vaccinate?
}

\author{
Helmy, A. ${ }^{1 *}$, Hasanain, A. ${ }^{1}$, Helmy, A.A. ${ }^{1}$, Ali, A. ${ }^{1}$, Samir, W. ${ }^{2}$, Soliman, R. ${ }^{2}$, \\ Shiha, G. ${ }^{2}$. \\ ${ }^{1}$ Tropical Medicine and Gastroenterology dept. Faculty of Medicine, Assiut Univ., Assiut, Egypt. \\ ${ }^{2}$ Gastroenterology \& Hepatology Unit, of Internal Medicine dept., Faculty of Medicine, Mansoura \\ Univ. \& Egyptian Liver Research Institute and Hospital, Mansoura, Egypt. \\ *E-mail: ahsalem10@yahoo.com
}

Article History Received: 2/7/2015 Revised: $18 / 9 / 2015$ Accepted: 28/9/2015

Keywords:

Superinfection

Coinfection

Dual infection

Viral hepatitis

Hepatitis A vaccination serology of hepatitis A

\begin{abstract}
:
Superinfection of patients with chronic liver disease (CLD) with hepatitis A virus (HAV) may have deleterious effects including hepatic decompensation and fulminant liver failure. The status of HAV infection in these patients needs to be assessed, especially after the availability of an effective HAV vaccine. This study aimed to assess the rate of HAV serology testing in patients with CLD, and their susceptibility to HAV superinfection. Patients and Methods: A total of 638 patients with CLD (Mean \pm SD age 46.2 \pm 15.8 years, 396(62.1\%) males), 517(81\%) of them had viral etiology were included. Total anti-HAV, which detect both IgG and IgM; and anti-HAV IgM were tested by a micro particle enzymatic assay (AxSYM system (Abbott Diagnostics, USA). Results: HAV serology was done in 190(29.8\%) patients, Mean $\pm S D$ age $46.2 \pm 15.8$ years $106(55.8 \%)$ were males, $119(62.6 \%)$ of them had viral etiology. Of these, 33(17\%) patients had negative anti-HAV IgG. Positive anti-HAV IgM was accidentally detected in 7(3.7\%) patients. Compared to IgG positive patients (immune against HAV), patients with negative anti-HAV $\operatorname{IgG}$ (susceptible) had no gender difference $(p=0.089)$. Patients with nonverbal etiology were significantly more susceptible to HAV (OR: 5.2, 95\% CI 2.3-11.8; $p<0.001)$. Also, patients $>20$ years old, and those $>40$ years old had significantly more anti-HAV IgG seropositivity compared to those who are younger in age (OR: 11.4, 95\% CI 4.8-27; $p<0.0001$ and OR: 3.8, 95\% CI 1.7-8.6; $p<0.01$ respectively). Conclusions: Only $30 \%$ of CLD patients are tested for HAV serology, $17 \%$ of them are susceptible to HAV infection especially those who are younger and with non-viral etiology. Detection and vaccination of these subgroups is warranted to avoid superinfection with $H A V$.
\end{abstract}

Short Title: Hepatitis A in chronic liver disease

Abbreviations: $H A V$; hepatitis A virus. CLD; chronic liver disease. Ig; immunoglobulin. $S D$; standard deviation. OR: Odd ratio. HCV; hepatitis C virus. HBV; hepatitis $B$ virus

Conflict of Interest \& Financial disclosure: None 


\section{Introduction}

It is well known that acute hepatitis A virus (HAV) infection in patients with chronic liver disease (CLD) carries a higher mortality [1]. This outcome is further affected by the extent of preexistent liver damage and consequent liver dysfunction. The prognosis of acute HAV infection in subjects who are chronically infected with hepatitis B virus (HBV) or hepatitis $\mathrm{C}$ virus (HCV) infection, but with normal amino-transferases and liver histology is quite good and is similar to infection in otherwise completely healthy subjects. However, the risk of severe or fatal illness is high if the infection occurs in the presence of chronic hepatitis or liver cirrhosis [2]. Based on these data, the Advisory Committee on Immunization Practices has recommended that all patients with CLD should be immunized against HAV infection [3].To answer the question of

\section{Patients and Methods}

\subsection{Patients}

A total of 638 consecutive patients with chronic liver disease, followed up in the Gastroenterology \& Hepatology Clinic from January 2011 till December 2014, were included in this study. Chronic liver disease was defined as persistent elevation of serum aminotransferases level or persistent whether adult patients with CLD need a HAV vaccine to prevent HAV superinfection, it is important to determine the prevalence of protective IgG antibodies against HAV(anti-HAV $\mathrm{IgG}$ ) in this population. In developed countries, the prevalence of such antibodies in adults is low and hence, the recommendation of administering HAV vaccine in adult CLD patients routinely is not only justified, but may also be cost-effective [2,3]. Egypt has a high population of patients with CLD, especially those related to $\mathrm{HCV}$ infection [4-6]. Little is known about the prevalence of HAV seropositivity (immunity) or susceptibility in patients with CLD. Therefore, the present analysis was done to determine the seroprevalence of HAV infection in adult patients with CLD to assess the feasibility of routine HAV vaccination for such patients.

histopathologic evidence of liver injury for six months or more. Patients with cirrhosis or past medical history of HAV vaccination were excluded from this study. Chronic hepatitis B was diagnosed based on the presence of hepatitis B surface antigen (HBsAg) while chronic hepatitis $\mathrm{C}$ diagnosis 
relied on detection of antibodies against $\mathrm{HCV}$ (anti-HCV) and $\mathrm{HCV}$ ribonucleic acid (HCV RNA); markers for both $\mathrm{HBV}$ and HCV must be present in two tests, six months apart. Patients' electronic data were checked in the Power Chart System for evidence and results of serology testing for both anti-
HAV IgG and anti-HAV IgM antibodies. The characteristics of the 638 patients (target population) are listed in tab. (1). The study was approved by the Local Research Committee, and all blood tests were done after obtaining patients' consent.

Table (1) Characteristics of all patients and those tested for hepatitis A virus serology

\begin{tabular}{|c|c|c|c|}
\hline \multicolumn{2}{|l|}{ Variable } & $\begin{array}{c}\text { All patients } \\
(\mathrm{n}=638)\end{array}$ & $\begin{array}{l}\text { Patients tested for HAV } \\
\qquad(\mathrm{n}=190)\end{array}$ \\
\hline \multirow[t]{4}{*}{ Age (years) } & Mean \pm SD & $46.2 \pm 15.8$ & $40.5 \pm 17.1$ \\
\hline & $>20$ years & 585 (91.7) & $157(82.6)$ \\
\hline & $>30$ years & $523(82.0)$ & $132(69.5)$ \\
\hline & $>40$ years & $428(67.1)$ & $108(56.8)$ \\
\hline \multirow[t]{2}{*}{ Sex } & Male: n (\%) & $396(62.1)$ & $106(55.8)$ \\
\hline & Female: n (\%) & $242(37.9)$ & $84(44.2)$ \\
\hline \multirow[t]{5}{*}{ Etiology } & Non-viral: $\mathrm{n}(\%)$ & $121(19.0)$ & $71(37.4)$ \\
\hline & Viral: n (\%) & $517(81.0)$ & $119(62.6)$ \\
\hline & $H C V$ & $384(60.2)$ & 83 (43.7) \\
\hline & $H B V$ & $63(9.9)$ & $22(11.6)$ \\
\hline & $H C V \& H B V$ & $70(10.9)$ & $14(7.4)$ \\
\hline
\end{tabular}

HAV: hepatitis A virus. HCV: hepatitis $C$ virus. HBV: hepatitis $B$ virus. $n$ : number. SD: standard deviation

\subsection{Hepatitis $A$ virus serology}

Sera were tested for total antiHAV which detect both IgG and IgM; and for anti-HAV IgM by using AxSYM system (Abbott Diagnostics, USA), which apply a micro particle enzymatic assay. Briefly; the anti-HAV in samples bound to the micro particles, the resulting complex was then transferred to the glass fiber matrix where the conjugate (anti-HAV labeled antibody) was added which then combined with the unbound HAV sites. The AxSYM System calculates a result based on the ratio of the sample rate to the index calibrator mean rate for each sample and control. For the total anti-HAV; samples with a cutoff values in the range of 1.0 to 3.0 were considered non reactive and samples with a cutoff values in the range of 0.0 to 1.0 were considered to be reactive for the total anti-HAV. For antiHAV IgM; samples with a cut-off values $>1.2$ were considered reactive, and samples with a cut-off values $<0.8$ were considered nonreactive. 


\subsection{Statistical analysis}

Data were collected in a predesigned data collection form before being entered in a Microsoft office Excel 2003 work sheet. Descriptive and comparative statistics were performed using the Statistical Package for Social Sciences software (SPSS, version 15,

Chicago, IL, USA). Data are expressed as Mean \pm Standard deviation (SD) or number and percentage as appropriate. Categorical variables were compared with the $\chi^{2}$ test. A p-value of $<0.05$ was considered statistically significant.

\section{Results}

Out of 638 patients with chronic chronic liver disease (HCV in $51.1 \%$, liver diseases, only 190 (29.8\%) were HBV in $18.9 \%$, and combined infection tested for anti-HAV (study population). Our study population was 190 patients with chronic liver disease who were tested for anti-HAV. The characteristics of study population are listed in tab. (2). Their mean \pm SD age was $46.2 \pm 15.8$ years, $106(55.8 \%)$ were males, and 119 $(62.6 \%)$ of them had viral etiology of in $7.4 \%$ ). Out of the 190 patients, 33 (17 $\%)$ patients were negative for both antiHAV IgG and anti-HAV IgM and thus, susceptible to HAV infection. Patterns of the study patients according to gender, age group, etiology of chronic disease, and HAV immune status are listed in tab. (1).

Table (2) Comparison between the HAV susceptible and immune Patients

\begin{tabular}{|c|c|c|c|c|c|c|}
\hline \multicolumn{2}{|l|}{ Variable } & $\begin{array}{c}\text { Susceptible } \\
\qquad(\mathrm{n}=\mathbf{3 3})\end{array}$ & $\begin{array}{l}\text { Others } \\
(n=157)\end{array}$ & $P$ value & Odd Ratio & $95 \%$ CI \\
\hline Sex & $\begin{array}{l}\text { Male } \\
\text { Female }\end{array}$ & $\begin{array}{l}14(42.4) \\
19(57.6)\end{array}$ & $\begin{array}{l}92(56.6) \\
65(43.4)\end{array}$ & 0.089 & 0.5 & $0.2-1.1$ \\
\hline Etiology* & $\begin{array}{l}\text { Non-viral } \\
\text { Viral }\end{array}$ & $\begin{array}{l}23(69.7) \\
10(30.3)\end{array}$ & $\begin{array}{l}48(30.6) \\
109(69.4)\end{array}$ & $<0.0001$ & 5.2 & $2.3-11.8$ \\
\hline \multirow{3}{*}{ Age } & $\begin{array}{l}>40 \text { years } \\
\leq 40 \text { years }\end{array}$ & $\begin{array}{l}23(69.7) \\
10(30.3)\end{array}$ & $\begin{array}{l}59(37.6) \\
98(62.4)\end{array}$ & $<0.01$ & 3.8 & $1.7-8.5$ \\
\hline & $\begin{array}{l}>30 \text { years } \\
\leq 30 \text { years }\end{array}$ & $\begin{array}{l}21(63.6) \\
12(36.2)\end{array}$ & $\begin{array}{c}37(23.6) \\
120(76.4)\end{array}$ & $<0.001$ & 5.7 & $2.6-12.6$ \\
\hline & $\begin{array}{l}>20 \text { years } \\
\leq 20 \text { years }\end{array}$ & $\begin{array}{l}18(54.5) \\
15(45.5)\end{array}$ & $\begin{array}{c}15(9.6) \\
142(90.4)\end{array}$ & $<0.0001$ & 11.4 & $4.8-27.0$ \\
\hline
\end{tabular}

HAV; hepatitis A virus. $n$, number. CI; confidence interval. *etiology of chronic liver disease. 


\subsection{Seroprevalence of HAV antibody according to gender}

Compared to anti-HAV IgG

susceptible to HAV infection) had no positive patients (classified as immune gender difference (OR: 0.5, $95 \% \mathrm{CI}$ : against HAV infection), patients with 0.2-1.1); tab. (2). negative anti-HAV IgG (classified as

\subsection{Seroprevalence of HAV antibody according to disease etiology}

Patients with non-viral etiology viral etiology (OR: 5.2, $95 \%$ CI 2.3were significantly more susceptible to 11.8; p <0.001); tab. (2).

HAV infection compared to those with

\subsection{Seroprevalence of HAV antibody according to age}

Patients $>20$ years old, those $>30$ years old, and those $>40$ years old had significantly more anti-HAV IgG seropositivity compared to those who are younger (OR: 11.4, 95 \% CI 4.8-27; p $<0.0001$, OR: 5.7, $95 \%$ CI: 2.6-12.6; p

\section{Discussion}

Improvement of socioeconomic status, sanitation, and hygiene practices in many developing countries have changed the epidemiologic pattern of HAV infection and decreased the incidence of HAV infection in young adults resulting in a reduction in individuals with protective anti-HAV antibodies and an increased incidence of acute hepatitis $\mathrm{A}$ in the adult population [7,8]. In addition, a more severe or even a fulminant course of HAV infection in patients with chronic liver disease was reported by several studies [9-11].
$<0.001$, and OR: 3.8, $95 \%$ CI 1.7-8.6; p $<0.01$ respectively). It should be noted that with younger ages, the Odds ratio of being more susceptible to HAV infection is higher (11.4 versus 5.7 versus 3.8; tab. (2).

According to the current data, only $30 \%$ of patients with CLD get tested for HAV serology in our locality. This indicates that doctors need to be more aware of the need to test high risk groups. In addition, HAV serology need to be tested in patient with CLD with recent decompensation of deterioration. We believe that, the more the number of patients who get tested, the higher the number of susceptible cases to HAV infection will be discovered, the higher the number of those who will need to be vaccinated. A similar case was reported 
in Saudi Arabia, where many studies [12-15] have shown that there is an epidemiologic shift and a marked decline in the prevalence of HAV infection in Saudi children and adolescents. This calls for a strict adherence to vaccination policies in high risk groups including patients with CLD. In our study, among patients with chronic liver disease, seroprevalence of HAV infection reached $83 \%$ (including $3.7 \%$ with antiHAV IgM). Regarding the remaining susceptible patients (17 \%), when considering the age, it was found that the highest rate of susceptibility(45.5\%, $36.2 \%$, and $30.3 \%$ of susceptible patients) was in patients older than 20 , 30 , and 40 years, respectively. This denotes the decline of susceptibility rate with advance of age. The overall rate of susceptibility was close to that reported among Italian (14.3\%) and Korean (20 $\%)$ patients with chronic liver disease $[16,17]$; but it was much lower than what was reported among Indian patients with chronic liver disease $(93.2 \%)$ most probably due to lower standards of hygiene [18]. Data of our study imply that a considerable percentage of our chronic liver disease patients are susceptible to HAV infection, and vaccinating them against HAV should be considered, especially those younger than 20 years. In the present study, the susceptibility rate for HAV infection in patients 30 years old or younger was $63.3 \%$, which is higher than what was reported among the same age group of Saudi persons without chronic liver disease $(48.8 \%)$ by Arif and colleagues [19]. This may reflect higher fast-food contamination in Egypt or may indicate that the immune response to HAV infection is impaired by chronic liver disease. In our study, younger age was significantly associated with susceptibility to HAV infection as expected. Also, viral etiology of chronic liver disease was associated with seroprevalence of HAV. This may reflect the relatively low socioeconomic status of the patients with hepatitis $\mathrm{C}$ or $\mathrm{B}$ infection or their older age. In the present study, susceptibility rate for HAV infection was slightly higher in females compared to males (57.6\% versus $42.2 \%$ ). This might infer better hygiene by females. In addition, it may be explained by more availability of clean water and good sanitation indoors and/or more exposure to contaminated foods and drinks outdoors. The current study has few limitations. First, epidemiological data on HAV infection was limited due to the retrospective 
design of the study. Data on the socioeconomic characteristics, including the educational level, annual income, the family size, the residence, and the water supply and sewage disposal were not included. Second, although the current study included a relatively large number of CLD patients, it was carried out at a single medical center. Therefore, the patients may not be representative of the population of different regions of the country.

\section{Conclusion}

Only $30 \%$ of patients with CLD get tested for HAV serology. This indicates that doctors need to be more aware of the need to test high risk groups. The susceptibility to HAV infection among patients with chronic liver disease is not low $(17.4 \%$, with highest one among patients 20-year-old or younger). Therefore, vaccination against HAV should be considered, particularly for young, anti-HAV-negative patients with chronic liver disease.

\section{References}

[1] Sinha, S., Singh, K., (2004). Acute on chronic liver disease in reference to hepatitis B. In: Sarin S., Singal A (eds.) Hepatitis $B$ in India: Prevention and Management. New Delhi: CBS Publishers and Distributors: 148-160.

[2] Keeffe, E., (1995). Is hepatitis A more severe in patients with chronic hepatitis B and other chronic liver diseases?. Am J. Gastroenterol; 90: 201-205.

[3] Cooksley, W., (2000). Consensus statement on the role of hepatitis A vaccination in patients with chronic liver disease. J. Viral Hepat.; 7 (Suppl 1): 29-30.
[4] Abdel-Wahab, M., Zakaria, S., Kamel, M., et al., (1994). High seroprevalence of hepatitis $\mathrm{C}$ infection among risk groups in Egypt. Am J. Trop Med Hyg; 51: 563-567.

[5] El Gohary, A., Hassan, A., Nooman, Z., et al., (1995). High prevalence of hepatitis $\mathrm{C}$ virus among urban and rural population groups in Egypt. Acta Trop; 59: 155-161.

[6] Waked, I., Doss, W., El-Sayed, M., Estes, C., Razavi, H., Shiha, G., Yosry, A., Esmat, G., (2014). The current and future disease burden of chronic hepatitis $\mathrm{C}$ virus infection in Egypt. Arab J. Gastroenterol.; 15: 4552. 
[7] Melnick, J., (1995). History and epidemiology of hepatitis A virus. $\boldsymbol{J}$. Infect Dis; 171 (Suppl 1): S2-S8.

[8] Lee, T., Kim, S., Lee, G., Im, E., Huh, K., Choi, Y., Kang, Y., (2006). Clinical features of acute hepatitis $\mathrm{A}$ in the Western part of Daejeon and Chungnam province: single center experience. Korean J. Gastroenterol; 47: 136-143.

[9] Akriviadis, E., Redeker, A., (1989). Fulminant hepatitis A in intravenous drug users with chronic liver disease. Ann Intern Med; 110: 838-839.

[10] Moon, H., Cho, J., Hur, M., Yun, Y., Choe, W., Kwon, S., Lee, C., (2010). Laboratory characteristics of recent hepatitis A in Korea: Ongoing epidemiological shift. World $\boldsymbol{J}$. Gastroenterol; 16: 115-118.

[11] Vento, S., Garofano, T., Renzini, C., Cainelli, F., Casali, F., Ghironzi, G., et al., (1998). Fulminant hepatitis associated with hepatitis A superinfection in patients with chronic hepatitis C. N Engl J Med; 338: 286290.

[12] Singal, A., Tadros, N., (2002). Profile of hepatocellular carcinoma in Jizan, Saudi Arabia: a retrospective study. $\boldsymbol{J}$. Gastroenterol Hepatol; 17 (Suppl 3): A1028.
[13] Fathalla, S., Al-Jama, A., AlSheikh, I., Islam, S., (2000). Seroprevalence of hepatitis A virus markers in Eastern Saudi Arabia. Saudi Med J.; 21: 945-949.

[14] Al Faleh, F., Al Ansari, S., Al Jeffri, M., Shaffi, A., Abdo, A., (2008). Changing patterns of hepatitis A prevalence within the Saudi population over the last 18 years. World $\boldsymbol{J}$. Gastroenterol; 14: 7371-7375.

[15] Almuneef, M., Memish, Z., Balkly, H., Qahtani, M., Al Otaibi, B., Hajeer, A., Qasim, L., Al knawy, B., (2006). Epideiologic shift in the prevalence of hepatitis A virus in Saudi Arabia: A case for routine hepatitis A vaccination. Vaccine; 24: 5599-5603.

[16] Stroffolini, T., Almasio, P., Di Stefano, R., Andreone, P., Di Gaetano, G., Fattovich, G., et al., (2002). Antihepatitis A virus seroprevalence and seroconversion in a cohort of patients with chronic viral hepatitis. Digest Liver Dis; 34: 656-659.

[17] Cho, H., Paik, S., Kim, Y., Choi, M., Lee, J., Koh, K., Yoo, B., Son, H., Kim, S., (2011). Seroprevalence of anti-HAV among patients with chronic viral liver disease. World $\boldsymbol{J}$. Gastroenterol; 17: 236-241. 
[18] Joshi, N., Rao, S., Kumar, A., Patil, S., Rani, S., (2007). Hepatitis A vaccination in chronic liver disease: is it really required in a tropical country like India? Indian J. Med Microbiol; 25: 137-139.
[19] Arif, M., Al-Faleh, F., Al-Frayh, A., Ramia, S., (1995). Reduction in the prevalence of antibody to hepatitis A virus among young Saudi adults: implications for hepatitis A vaccine. Saudi J Gastroenterol; 1: 93-96. 